\title{
The Mediterranean Oscillation Teleconnection Index: Station-Based versus Principal Component Paradigms
}

\author{
Francisco Criado-Aldeanueva and F. Javier Soto-Navarro \\ Physical Oceanography Group, Department of Applied Physics II, University of Málaga, 29071 Málaga, Spain \\ Correspondence should be addressed to Francisco Criado-Aldeanueva; fcaldeanueva@ctima.uma.es
}

Received 15 September 2013; Revised 23 October 2013; Accepted 29 October 2013

Academic Editor: Anthony R. Lupo

Copyright (c) 2013 F. Criado-Aldeanueva and F. J. Soto-Navarro. This is an open access article distributed under the Creative Commons Attribution License, which permits unrestricted use, distribution, and reproduction in any medium, provided the original work is properly cited.

\begin{abstract}
Two different paradigms of the Mediterranean Oscillation (MO) teleconnection index have been compared in this work: stationbased definitions obtained by the difference of some climate variable between two selected points in the eastern and western basins (i.e., Algiers and Cairo, Gibraltar and Israel, Marseille and Jerusalem, or south France and Levantine basin) and the principal component (PC) approach in which the index is obtained as the time series of the first mode of normalised sea level pressure anomalies across the extended Mediterranean region. Interannual to interdecadal precipitation $(P)$, evaporation $(E), E-P$, and net heat flux have been correlated with the different $\mathrm{MO}$ indices to compare their relative importance in the long-term variability of heat and freshwater budgets over the Mediterranean Sea. On an annual basis, the PC paradigm is the most effective tool to assess the effect of the large-scale atmospheric forcing in the Mediterranean Sea because the station-based indices exhibit a very poor correlation with all climatic variables and only influence a reduced fraction of the basin. In winter, the station-based indices highly improve their ability to represent the atmospheric forcing and results are fairly independent of the paradigm used.
\end{abstract}

\section{Introduction}

The Mediterranean Sea (Figure 1(a)), a semi-enclosed basin that extends over $3000 \mathrm{~km}$ in longitude and over $1500 \mathrm{~km}$ in latitude with an area of $2.5 \cdot 10^{12} \mathrm{~m}^{2}$, communicates with the Atlantic Ocean through the Strait of Gibraltar and with the Black Sea through the Turkish Bosphorus and Dardanelles Straits. An Atlantic inflow through the Strait of Gibraltar is necessary to balance the freshwater and salt budgets since evaporative losses $(E)$ are not balanced by precipitation $(P)$ and river runoff $(R)$. The circulation in the Mediterranean Sea is influenced to a large extent by the heat and freshwater air-sea exchanges which depend on the meteorological and oceanic conditions [1] and they also play a key role in dense water formation and hence in the Mediterranean Thermohaline Circulation [2]. As a consequence, they affect the characteristics of the Mediterranean water masses and then may potentially influence the Atlantic Ocean circulation via changes in the properties of the Mediterranean Outflow [2-5]. For these reasons, the improvement of our knowledge of heat and water budgets and their long-term variability is a challenge for the scientific community of the Mediterranean region and is thought to be crucial to understand the Mediterranean circulation and climate and their evolution under climate change.

Indices of large-scale climate modes are very helpful to this aim since they provide an integrated measure of weather linked more to the overall physical variability of the system than to any individual local variable. Among these indices, the North Atlantic Oscillation (NAO) is one of the most prominent modes of the northern hemisphere climate variability (see [6-8]; [9] for a recent review). Other modes such as the East-Atlantic (EA) [10-12], the East-Atlantic-West Russia (EA-WR) [10-12], or the North Sea-Caspian Pattern (NCP) [13-16] also have a major impact on various meteorological parameters in the Mediterranean basin and Europe. But more specifically for the Mediterranean Sea, Conte et al. [17] suggested the possible existence of a Mediterranean Oscillation (MO) as a consequence of the dipole behaviour of the atmosphere in the area between the western and eastern Mediterranean. Differences in temperature, precipitation, circulation, and other parameters between both basins were 


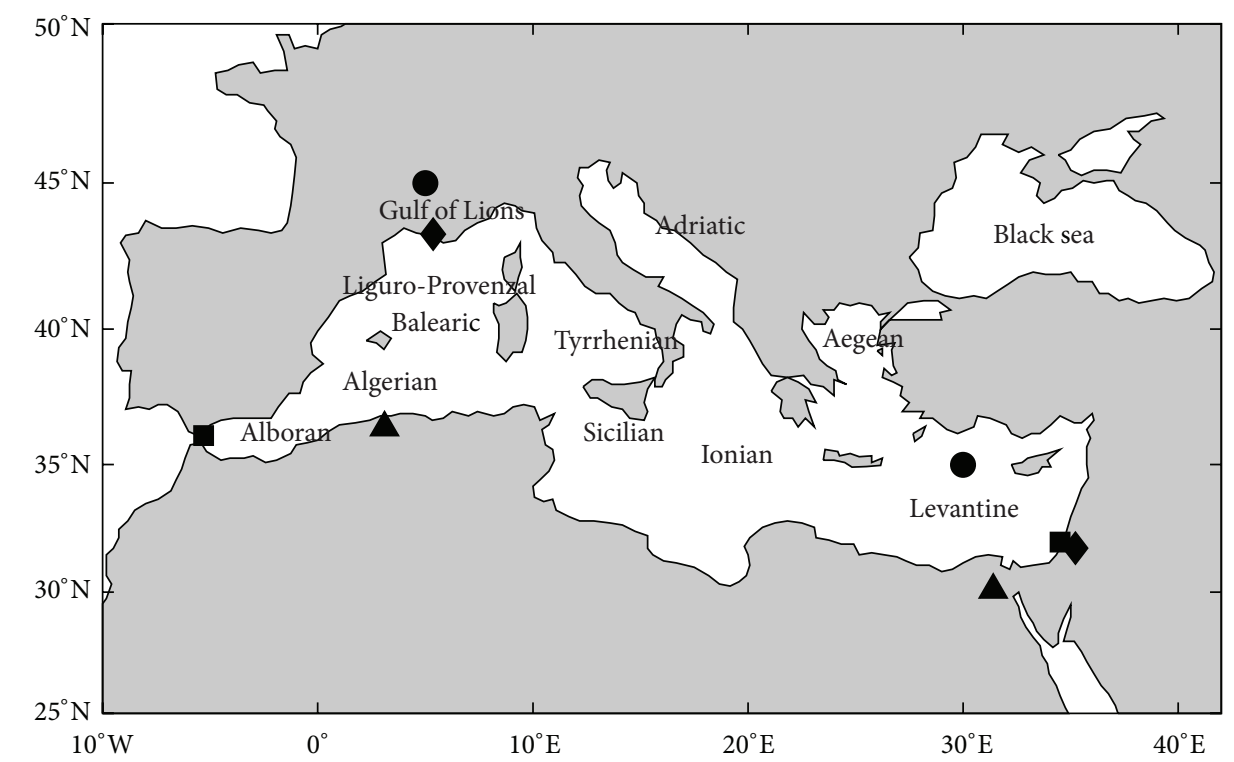

(a)

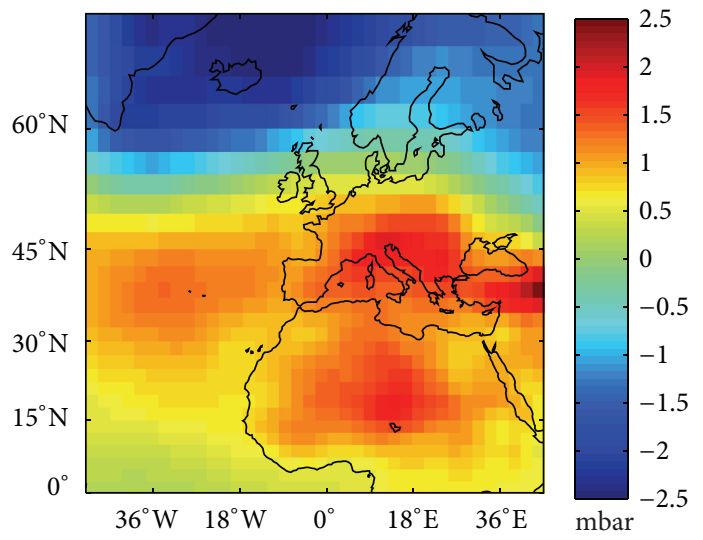

(b)

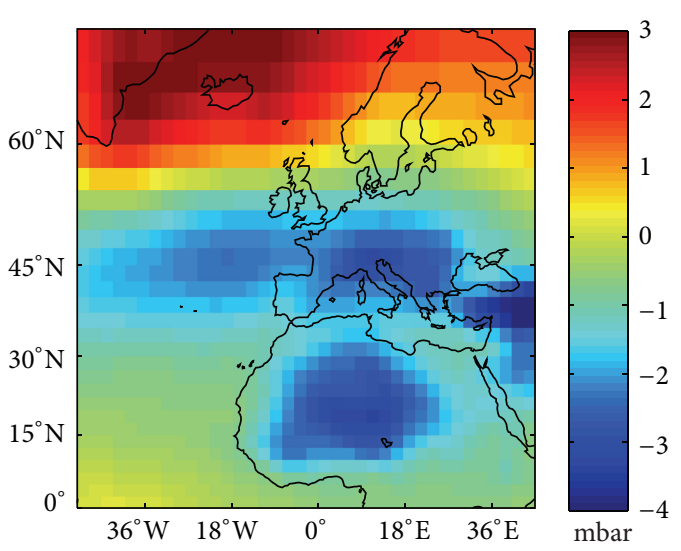

(c)

Figure 1: (a) Map of the Mediterranean Sea. The main basins and subbasins are indicated. Symbols are placed in the locations selected for pressure differences in the station-based MO indices (a triangle for Algiers-Cairo, a square for Gibraltar-Israel, a circle for France-Levantine, and a diamond for Marseille-Jerusalem). ((b)-(c)) Composites of sea level pressure anomalies (mbar) in the 1958-2008 period during the positive (higher quartile, (b)) and negative (lower quartile, (c)) phases of the $\mathrm{MO}_{\mathrm{PC}}$ index.

attributed to this MO [17-22] and an index to measure the intensity of this dipole-like behaviour was proposed.

Climatic indices have been traditionally derived either from the simple difference of some climate variable between two locations or from the Principal Components (PC) approach. Conte et al. [17] defined MO index as the normalised $500 \mathrm{hPa}$ geopotential heights difference between Algiers $\left(36.4^{\circ} \mathrm{N}, 3.1^{\circ} \mathrm{E}\right)$ and Cairo $\left(30.1^{\circ} \mathrm{N}, 31.4^{\circ} \mathrm{E}\right)$. A second version of the index [23] can be calculated based on sea level pressure differences between Gibraltar northern frontier $\left(36.1^{\circ} \mathrm{N}, 5.3^{\circ} \mathrm{W}\right)$ and Lod Airport Israel $\left(32.0^{\circ} \mathrm{N}, 34.5^{\circ} \mathrm{E}\right)$. In order to obtain an index more suitable for the Central Mediterranean, Brunetti et al. [24] defined MO index as the normalized sea level pressure difference between Marseille and Jerusalem. This index was found to present good correlation with total precipitation and number of wet days in Italy [24]. More recently Papadopoulos et al. [11, 12] introduced the Mediterranean index as the sea level pressure difference between south France $\left(45^{\circ} \mathrm{N}, 5^{\circ} \mathrm{E}\right)$ and Levantine Sea $\left(35^{\circ} \mathrm{N}, 30^{\circ} \mathrm{E}\right)$. These two points are orientated in a NW-SE direction and are likely to reflect more accurately the realistic dipole pressure pattern. Within the PC approach, Suselj and Bergant [25] proposed a MO index definition based on EOF analysis of sea level pressure anomaly fields over an extended Mediterranean region and Gomis et al. [26] also adopted this definition to study its influence in the flow exchange through Gibraltar.

In contrast to NAO and the other teleconnection indices, which have been extensively studied, only a few previous works focus on the MO index and more research is required. In this work, we compare the influence of the different MO indices in heat and water budgets in the Mediterranean Sea. 
To this aim, we correlate interannual to interdecadal precipitation, evaporation, freshwater budget $(E-P)$, and net heat flux with MO indices to establish their relative importance in the climatic variables. The work is organised as follows: Section 2 describes the data and methodology; Section 3 presents and discusses the results both from a regional and global approach, and finally Section 4 summarises the conclusions.

\section{Data and Methodology}

Several MO definitions, traditionally used in the literature, have been used for comparison: the Algiers-Cairo MO index $\left(\mathrm{MO}_{\mathrm{AC}}\right)$ has been computed following the definition of Conte et al. [17] and the Gibraltar-Israel MO index $\left(\mathrm{MO}_{\mathrm{GI}}\right)$ following that of Palutikof [23], defined in Section 1. Daily records of these two indices have been obtained from the Climate Research Unit (University of East Anglia) for the period 19582008 and seasonal and annual means have been obtained by averaging daily values. Monthly values of the MarseilleJerusalem $\mathrm{MO}$ index $\left(\mathrm{MO}_{\mathrm{MJ}}\right)$ have been computed according to Brunetti et al. [24] from the sea level pressure database of the National Center for Environmental Prediction (NCEP) National Center of Atmospheric Research (NCAR), referred as NCEP hereinafter [27]. Monthly time series of the FranceLevantine $\mathrm{MO}$ index $\left(\mathrm{MO}_{\mathrm{FL}}\right)$, introduced by Papadopoulos et al. [11, 12], have been kindly received from Dr. Papadopoulos. The MO spatial pattern from the PC approach has been computed as the first mode of normalised sea level pressure anomalies across the extended Mediterranean region $\left(30^{\circ} \mathrm{W}-40^{\circ} \mathrm{E}\right.$ in longitude, $30^{\circ} \mathrm{N}-60^{\circ} \mathrm{N}$ in latitude) which exhibits a single centre located over the Central and Western Mediterranean, which remains fairly steady in all seasons. The $\mathrm{MO}$ index $\left(\mathrm{MO}_{\mathrm{PC}}\right)$ is then obtained as the corresponding time coefficients of the first PC mode. Since we define the positive phase when sea level pressure anomaly above the Mediterranean is positive, $\mathrm{MO}_{\mathrm{PC}}$ and all the other $\mathrm{MO}$ indices will be positively correlated.

Monthly means from January 1958 to December 2008 of precipitation, evaporation, and surface heat fluxes have been retrieved from the NCEP reanalysis project, which is run at T62 spectral resolution (approximately a grid size of $1.9^{\circ} \times 1.9^{\circ}$ ) with 28 sigma levels. Auxiliary data of monthly mean sea level pressure at $2.5^{\circ} \times 2.5^{\circ}$ for the period 19582008 have also been retrieved from the NCEP database. Seasonal means have been computed by averaging JFM (winter), AMJ (spring), JAS (summer), and OND (autumn) monthly data and Mediterranean spatially averaged time series have been obtained by averaging all grid points over the sea. Linear correlation maps have been used to identify coupled patterns between the climatic variables and the MO indices. The statistical significance of the correlation has been computed by transforming the correlation matrix in a $t$ student distribution with $N-2$ degrees of freedom, where $N$ is the number of element of the analysed time series. With this procedure, each time series of a specific grid point for any of the variables is transformed into a $t$ statistic used to compute the probability of getting a correlation as large as the observed value by random chance, when the true correlation is zero. If the obtained value is small (in our case lower than 0.05) then the correlation is considered significant. Time filtering into low and high frequency components is achieved using a 5-year running mean to take into account the long time scale effects of the indices. A complementary composite analysis has also been performed to highlight the asymmetries between the positive and negative phases of the indices, defined as the upper and lower quartiles of the MO time series over the period 1958-2008. The effect in the climatic variables is computed in terms of the average anomalies during the positive/negative phases of the indices with respect to the complete time series on each grid point. Only the points where the results are statistically different from zero (according to a Student's $t$-test at $95 \%$ significance) have been represented.

\section{Results and Discussion}

3.1. Annual and Interannual Variability. Table 1 shows the correlation (absolute value) between the climatic variables and the different MO indices analysed. On an annual basis (upper panel), the $\mathrm{MO}_{\mathrm{PC}}$ index gives the best correlation for all variables and also influences more extensive areas of the basin (in brackets, the fraction of points significantly correlated). At decadal timescales (5-year running means), the indices tend to increase the correlation, especially $\mathrm{MO}_{\mathrm{PC}}$ that influences most of the Mediterranean (see Figure 2). Pettenuzzo et al. [28] highlighted the importance of the choice of a long period (i.e., decadal variations) for budget studies in the Mediterranean, since the long time scale effects of the indices must be taken into account because of their direct implication on the climatic variables. Basin-wide, $\mathrm{MO}_{\mathrm{PC}}$ shows again the highest correlation with $P(-0.74), E$ $(-0.53)$, and $Q(-0.71)$ and among the station-based indices, $\mathrm{MO}_{\mathrm{AC}}$ gives a reasonably good correlation with $E-P(0.53)$, whereas $\mathrm{MO}_{\mathrm{MJ}}$ provides good results for $P(-0.67)$; see Table 2.

Anticorrelation with $P$ is expected because the MO positive phase produces a sea level pressure anomaly field (Figure $1(\mathrm{~b})$ for $\mathrm{MO}_{\mathrm{PC}}$ ) that strengthens and modifies the orientation of prevailing westerly winds and associated storm-track activity which cause dry anomalies in the Mediterranean region, whereas the negative phase (Figure $1(\mathrm{c})$ for $\mathrm{MO}_{\mathrm{PC}}$ ) is linked to intense cyclogenesis over the central/western Mediterranean that produces anomalously wet conditions over most of the basin and hence negative correlation with $P$. Precipitation anomalies during the positive and negative phases (higher and lower quartiles) of the $\mathrm{MO}_{\mathrm{PC}}$ index (the other MO indices only affect a reduced area of the basin on annual basis) are shown in Table $3 . \mathrm{MO}_{\mathrm{PC}}$ exerts a strong influence with precipitation anomalies close to $100 \mathrm{~mm} /$ year on average over most of the basin. Higher anomalies are observed in the northern Mediterranean in both phases with values up to $-200 \mathrm{~mm} /$ year during the positive phase in the Ionian and Levantine subbasins and up to $250 \mathrm{~mm} /$ year during the negative phase in the Ionian and north Adriatic (Figures 3(a) and 3(b)).

Anticorrelation with $E$ is again expected since, in its negative phase, anomalously low pressure over the whole 
TABLE 1: (a) Mean absolute correlation at 95\% significance level between annual and decadal (5-year running means) MO indices and climatic variables $(P, E, E-P$, and net heat flux, $Q)$. The fraction of points significantly correlated is shown in brackets. (-) indicates that the correlation is not significant in more than $95 \%$ of the basin. (b) The same as above but for winter (JFM) season. The highest correlation for each variable is highlighted in bold.

(a)

\begin{tabular}{|c|c|c|c|c|c|c|c|c|c|c|}
\hline & \multicolumn{5}{|c|}{ Annual means } & \multicolumn{5}{|c|}{5 -year means } \\
\hline & $\mathrm{MOI}_{\mathrm{PC}}$ & $\mathrm{MOI}_{\mathrm{AC}}$ & $\mathrm{MOI}_{\mathrm{GI}}$ & $\mathrm{MOI}_{\mathrm{FL}}$ & $\mathrm{MOI}_{\mathrm{MJ}}$ & $\mathrm{MOI}_{\mathrm{PC}}$ & $\mathrm{MOI}_{\mathrm{AC}}$ & $\mathrm{MOI}_{\mathrm{GI}}$ & $\mathrm{MOI}_{\mathrm{FL}}$ & $\mathrm{MOI}_{\mathrm{MJ}}$ \\
\hline$P_{\text {NCEP }}$ & $0.46(59 \%)$ & $0.45(51 \%)$ & $0.33(6 \%)$ & $0.41(18 \%)$ & $0.44(40 \%)$ & $0.62(69 \%)$ & $0.57(51 \%)$ & $0.37(8 \%)$ & $0.40(32 \%)$ & $0.52(79 \%)$ \\
\hline$E_{\mathrm{NCEP}}$ & $0.45(47 \%)$ & - & - & $0.32(10 \%)$ & - & $0.58(58 \%)$ & - & - & $0.40(37 \%)$ & $0.43(44 \%)$ \\
\hline$E-P_{\mathrm{NCEP}}$ & $0.41(42 \%)_{d}$ & $0.26(26 \%)$ & $0.30(9 \%)$ & $0.38(30 \%)_{\mathrm{d}}$ & $0.41(27 \%)$ & $0.52(59 \%)_{d}$ & $0.52(46 \%)$ & $0.33(8 \%)$ & $0.41(29 \%)_{\mathrm{d}}$ & $0.45(42 \%)_{\mathrm{d}}$ \\
\hline$Q_{\mathrm{NCEP}}$ & $0.47(71 \%)$ & $0.39(33 \%)$ & - & $0.31(8 \%)$ & $0.34(11 \%)$ & $0.64(79 \%)$ & $0.37(20 \%)$ & - & $0.41(46 \%)$ & $0.48(68 \%)$ \\
\hline
\end{tabular}

(b)

\begin{tabular}{|c|c|c|c|c|c|c|c|c|c|c|}
\hline & \multicolumn{5}{|c|}{ Winter means } & \multicolumn{5}{|c|}{ 5-year winter means } \\
\hline & $\mathrm{MOI}_{\mathrm{PC}}$ & $\mathrm{MOI}_{\mathrm{AC}}$ & $\mathrm{MOI}_{\mathrm{GI}}$ & $\mathrm{MOI}_{\mathrm{FL}}$ & $\mathrm{MOI}_{\mathrm{MJ}}$ & $\mathrm{MOI}_{\mathrm{PC}}$ & $\mathrm{MOI}_{\mathrm{AC}}$ & $\mathrm{MOI}_{\mathrm{GI}}$ & $\mathrm{MOI}_{\mathrm{FL}}$ & $\mathrm{MOI}_{\mathrm{MJ}}$ \\
\hline$P_{\text {NCEP-W }}$ & $0.50(71 \%)$ & $0.55(73 \%)$ & $0.46(49 \%)_{d}$ & $0.46(55 \%)_{d}$ & $0.53(59 \%)$ & $0.66(81 \%)$ & $0.65(81 \%)$ & $0.57(72 \%)$ & $0.63(67 \%)_{d}$ & $0.65(77 \%)$ \\
\hline$E_{\mathrm{NCEP}-\mathrm{W}}$ & $0.39(38 \%)_{\mathrm{d}}$ & $0.50(49 \%)_{d}$ & $0.31(10 \%)_{\mathrm{d}}$ & $0.42(42 \%)_{\mathrm{d}}$ & $0.39(44 \%)_{\mathrm{d}}$ & $0.50(54 \%)$ & $0.49(49 \%)$ & $0.40(37 \%)_{\mathrm{d}}$ & $0.40(37 \%)_{\mathrm{d}}$ & $0.43(46 \%)$ \\
\hline$E-P_{\text {NCEP-W }}$ & ${ }_{V} 0.45(59 \%)$ & $0.42(59 \%)$ & $0.45(33 \%)$ & $0.43(48 \%)$ & $0.45(54 \%)$ & $0.60(77 \%)$ & $0.56(78 \%)$ & $0.55(76 \%)$ & $0.59(69 \%)$ & $0.59(79 \%)$ \\
\hline$Q_{\text {NCEP-W }}$ & $0.39(42 \%)_{\mathrm{d}}$ & $0.51(57 \%)_{\mathrm{d}}$ & $0.32(16 \%)_{\mathrm{d}}$ & $0.43(46 \%)_{\mathrm{d}}$ & $0.37(51 \%)_{\mathrm{d}}$ & $0.55(58 \%)$ & $0.53(57 \%)$ & $0.42(38 \%)$ & $0.40(39 \%)_{\mathrm{d}}$ & $0.47(45 \%)$ \\
\hline
\end{tabular}

TABLE 2: Correlation at $95 \%$ significance level between the MO indices and the Mediterranean-averaged variables $(P, E, E-P$, and net heat flux, $Q$ ) on annual basis (a) and for winter season (b) at decadal (5-year running means) timescale. (-) indicates that correlation is not significant. The highest correlation for each variable is highlighted in bold.

(a)

\begin{tabular}{lccccc}
\hline & \multicolumn{5}{c}{5 -year med-averaged annual basis } \\
& MOI $_{\mathrm{PC}}$ & $\mathrm{MOI}_{\mathrm{AC}}$ & $\mathrm{MOI}_{\mathrm{GI}}$ & $\mathrm{MOI}_{\mathrm{FL}}$ & MOI $_{\mathrm{MI}}$ \\
\hline$P_{\mathrm{NCEP}}$ & $-\mathbf{0 . 7 4}$ & -0.42 & - & -0.30 & -0.67 \\
$E_{\mathrm{NCEP}}$ & $-\mathbf{0 . 5 3}$ & - & - & - & -0.34 \\
$E-P_{\mathrm{NCEP}}$ & - & $\mathbf{0 . 5 3}$ & - & - & 0.28 \\
$Q_{\mathrm{NCEP}}$ & $-\mathbf{0 . 7 1}$ & - & - & -0.30 & -0.44 \\
\hline
\end{tabular}

(b)

\begin{tabular}{lccccc}
\hline & \multicolumn{5}{c}{ 5-year med-averaged winter } \\
& $\mathrm{MOI}_{\mathrm{PC}}$ & $\mathrm{MOI}_{\mathrm{AC}}$ & $\mathrm{MOI}_{\mathrm{GI}}$ & $\mathrm{MOI}_{\mathrm{FL}}$ & $\mathrm{MOI}_{\mathrm{MI}}$ \\
\hline$P_{\mathrm{NCEP}-\mathrm{W}}$ & $-\mathbf{0 . 8 7}$ & -0.82 & -0.67 & -0.62 & -0.79 \\
$E_{\mathrm{NCEP}-\mathrm{W}}$ & $\mathbf{- 0 . 3 5}$ & -0.32 & - & - & - \\
$E_{-} P_{\mathrm{NCEP}-\mathrm{W}}$ & 0.75 & 0.71 & 0.74 & 0.79 & $\mathbf{0 . 8 0}$ \\
$Q_{\text {NCEP-W }}$ & $-\mathbf{0 . 4 9}$ & -0.42 & - & - & - \\
\hline
\end{tabular}

basin is observed (see Figure 1(c) for $\mathrm{MO}_{\mathrm{PC}}$ ). This favors colder and dryer air masses from the continental regions that generate more severe weather conditions over the northern and eastern Mediterranean and hence an intensification of evaporative losses to the atmosphere $(109 \mathrm{~mm} /$ year on average, see Table 3, and values above $400 \mathrm{~mm} /$ year in the Levantine subbasin, Figure 3(d)). In this phase, the dipole of anomalously low pressure over Central Europe and Turkey (Figure 1(c)) brings colder and dryer air masses from continental regions to the Levantine subbasin that enhances evaporative losses in this area. Conversely, the positive MO
TABLE 3: Mediterranean averaged anomalies in the 1958-2008 period during the positive (higher quartile) and negative (lower quartile) phases of the selected $\mathrm{MO}_{\mathrm{PC}}$ index. Units are $\mathrm{mm} /$ year for $P, E$, and $E-P$ and $\mathrm{W} \mathrm{m}^{-2}$ for $Q$. Anomalies of opposite sign across the basin are shown separately by a /. The fraction of points where the anomaly is significantly different from zero is shown in brackets.

\begin{tabular}{|c|c|c|}
\hline & \multicolumn{2}{|c|}{$\mathrm{MO}_{\mathrm{PC}}$} \\
\hline & $\mathrm{CA}+$ & CA- \\
\hline$P_{\mathrm{NCEP}}$ & $-93.8(84 \%)$ & $88.0(72 \%)$ \\
\hline$E_{\mathrm{NCEP}}$ & $-83(92 \%)$ & $109.0(79 \%)$ \\
\hline$E-P_{\mathrm{NCEP}}$ & $78.3 /-75.3(62 \%)$ & $139.8 /-94.4(79 \%)$ \\
\hline$Q_{\mathrm{NCEP}}$ & $-10.3(92 \%)$ & $13.4(92 \%)$ \\
\hline
\end{tabular}

phase is associated with higher than average pressure over the Mediterranean and North Africa (Figure 1(b)) that promotes a shift of the wind trajectories toward lower latitudes. Warmer and moister air masses are then conveyed toward the Mediterranean leading to milder winters and a decrease in the evaporative lost, similarly as shown by Hurrell [29] for the NAO.

For the freshwater budget $(E-P)$, a clear bimodal pattern is observed at decadal timescales (see Figure 2(c) for $M_{\mathrm{PC}}$ ): in the North-Central Mediterranean, E-P is positively correlated (0.5-0.6) with $\mathrm{MO}_{\mathrm{PC}}$ index, whereas in the Levantine subbasin anticorrelation is observed (close to -0.6 ). This dipolar behaviour (subindex $\mathrm{d}$ in Table 1) can be explained based on the different sensitiveness of $E$ and $P$ to the $\mathrm{MO}_{\mathrm{PC}}$ index in those regions. In the Central basin, $P$ is dominant and changes in $E-P$ follow those of $-P$ (hence, positive correlation is expected). In contrast, the Levantine subbasin is highly sensitive to $E$ (see Figure 2(b) and discussion above) and changes in $E-P$ follow those of $E$ (hence, negative correlation). In this case, the negative phase of $\mathrm{MO}_{\mathrm{PC}}$ index exerts stronger influence (Table 3 ), with positive anomalies 


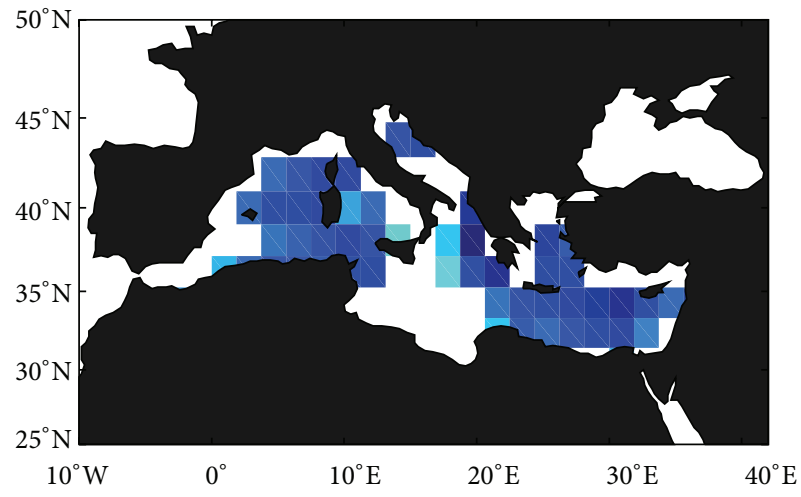

(a)

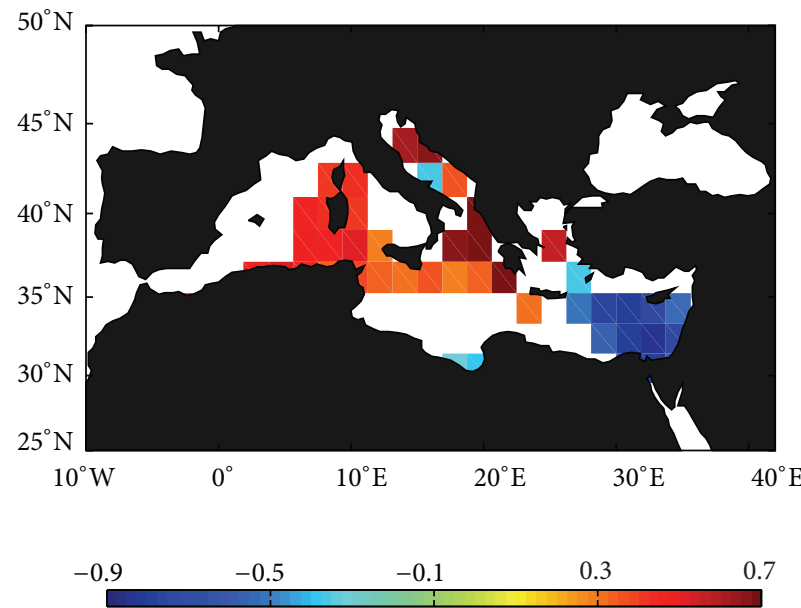

(c)

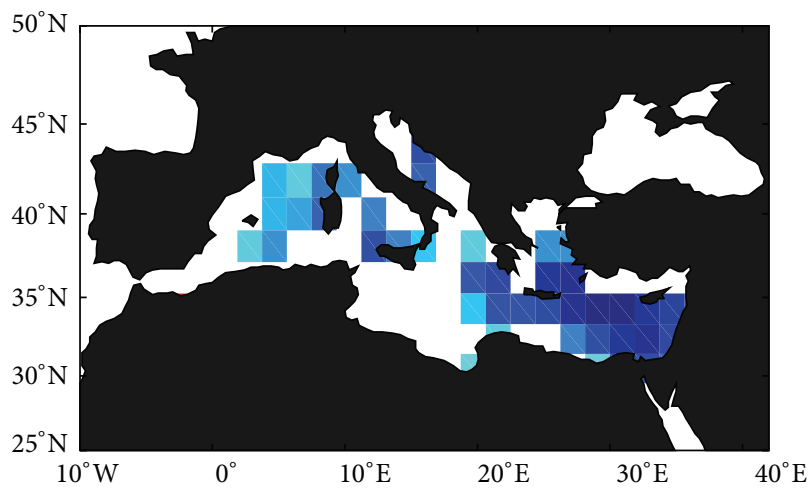

(b)

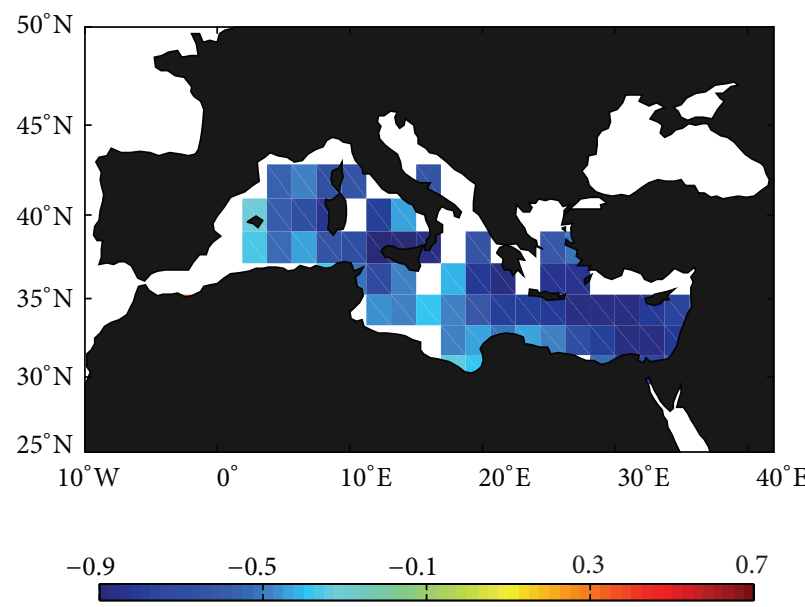

(d)

FIGURE 2: Correlation spatial pattern (95\% significance) between decadal (5-year running means) $\mathrm{MO}_{\mathrm{PC}}$ index and the selected climatic variables: precipitation (a), evaporation (b), freshwater budget $E-P$ (c), and net heat flux (d) for the period 1958-2008.

up to $400 \mathrm{~mm} /$ year in the Levantine basin and negative anomalies about $-200 \mathrm{~mm} /$ year above $35^{\circ} \mathrm{N}$ (Figure 3(f)).

As shown by Criado-Aldeanueva et al. [30], the net heat flux variability is mostly determined by the latent heat variability and this contribution becomes the main source of interannual variability. Since latent heat is directly related to evaporation, similarity between Figures 2(b) and 2(d) is expected and composite spatial patterns during the positive and negative phases (not shown) are very similar to those of $E$ (see Figures 3(c) and 3(d)). However, better correlation is observed with $\mathrm{MO}_{\mathrm{PC}}$ for net heat flux (see also Table 1) due to the contribution of the other components (i.e., sensible heat) that correlate well with $\mathrm{MO}_{\mathrm{PC}}$. Notice that the sign of the correlation is negative because we have selected net heat flux positive toward the atmosphere (the same as evaporation).

Correlation among the different $\mathrm{MO}$ indices is presented in Table 4. $\mathrm{MO}_{\mathrm{FL}}$ and $\mathrm{MO}_{\mathrm{MJ}}$ are highly correlated $(r=$ $0.76)$, as expected from the nearby locations selected for their definition, whereas $\mathrm{MO}_{\mathrm{GI}}$ is poorly correlated with most $\mathrm{MO}$ definitions. This explains the similar results of Table 1 for $\mathrm{MO}_{\mathrm{FL}}$ and $\mathrm{MO}_{\mathrm{MJ}}$ and the worse performance of $\mathrm{MO}_{\mathrm{GI}}$, whose orientation does not seem to catch accurately the realistic dipole pressure pattern. In summary, on an annual basis,
TABLE 4: Correlation (95\% significance level) among all the selected $\mathrm{MO}$ indices (annual time series): $\mathrm{MO}_{\mathrm{PC}}$ based on principal component analysis and the other station-based $\mathrm{MO}$ indices $\left(\mathrm{MO}_{\mathrm{AC}}\right.$ for Algiers-Cairo; $\mathrm{MO}_{\mathrm{GI}}$ for Gibraltar-Israel; $\mathrm{MO}_{\mathrm{FL}}$ for FranceLevantine; and $\mathrm{MO}_{\mathrm{MJ}}$ for Marseille-Jerusalem; see text for details).

\begin{tabular}{lcccc}
\hline & $\mathrm{MO}_{\mathrm{PC}}$ & $\mathrm{MO}_{\mathrm{AC}}$ & $\mathrm{MO}_{\mathrm{GI}}$ & $\mathrm{MO}_{\mathrm{FL}}$ \\
\hline $\mathrm{MO}_{\mathrm{AC}}$ & 0.41 & & & \\
$\mathrm{MO}_{\mathrm{GI}}$ & $\mathrm{n} . \mathrm{s}$ & 0.36 & & \\
$\mathrm{MO}_{\mathrm{FL}}$ & 0.50 & 0.42 & 0.40 & \\
$\mathrm{MO}_{\mathrm{MJ}}$ & 0.62 & 0.66 & 0.59 & 0.76 \\
\hline
\end{tabular}

the $\mathrm{MO}_{\mathrm{PC}}$ based on principal component analysis is the most effective teleconnection index to monitor heat and freshwater budgets in the Mediterranean Sea because the station-based indices exhibit a poor correlation with all climatic variables and only influence a reduced fraction of the basin.

3.2. Winter and Interwinter Variability. In winter (or even the cold part of the year), the atmosphere is dynamically more active and the ocean response to atmospheric forcing is higher. Large-scale patterns of atmospheric variability have 


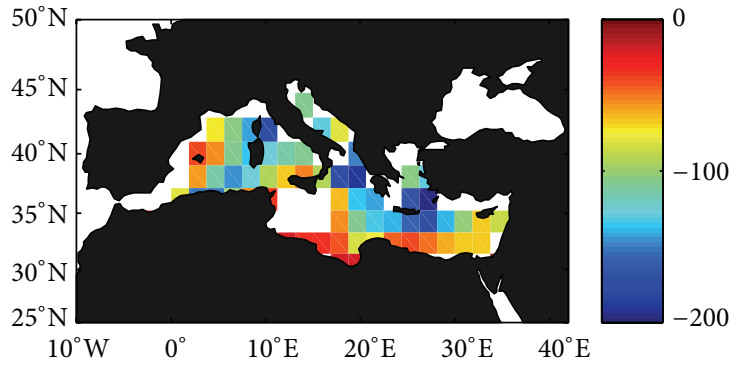

(a)

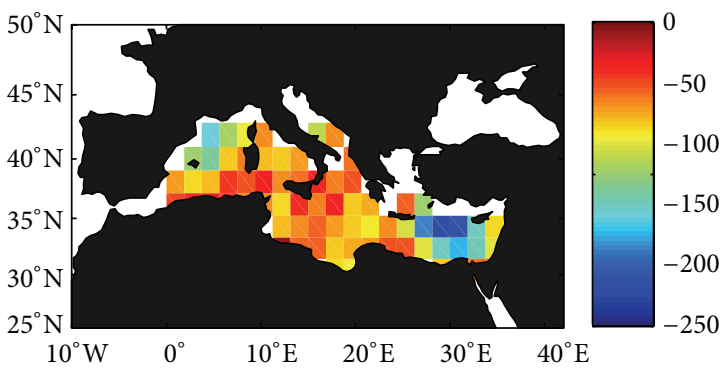

(c)

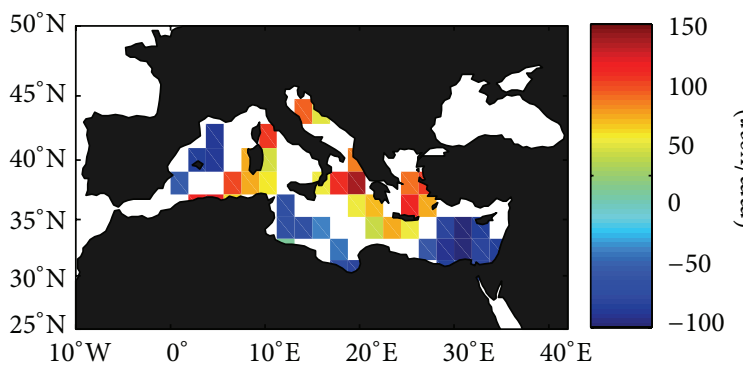

(e)

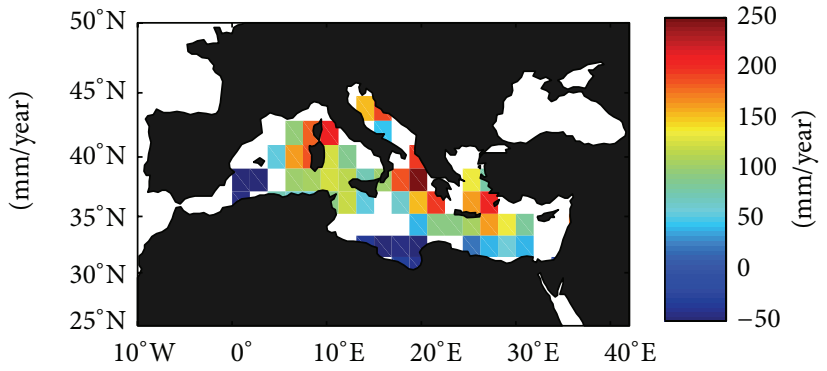

(b)

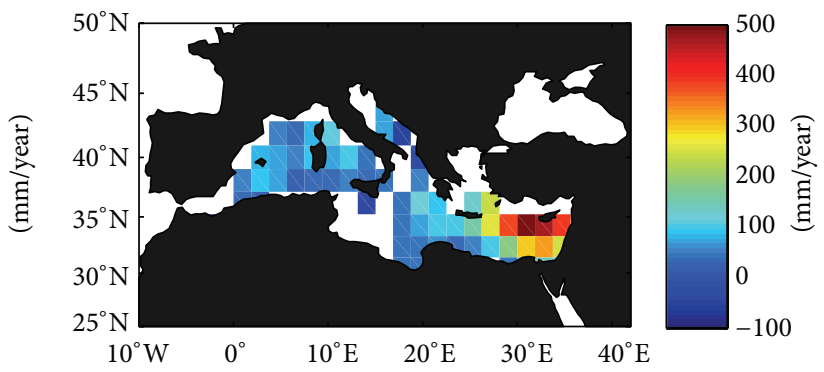

(d)

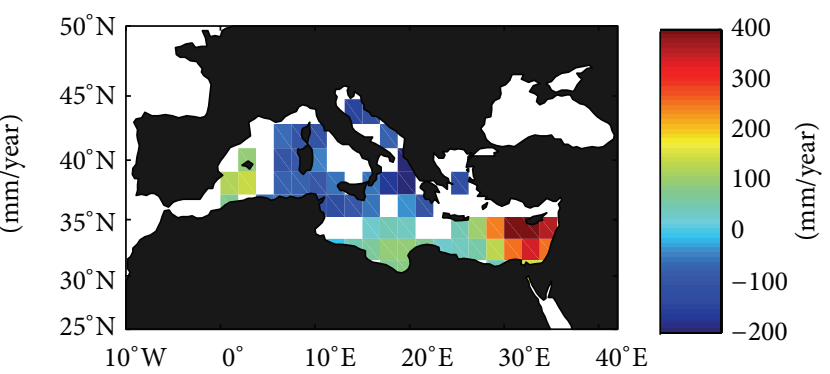

(f)

Figure 3: Composite of precipitation ((a)-(b)), evaporation ((c)-(d)), and freshwater budget $E-P((\mathrm{e})$-(f)) anomalies (mm/year) under the positive (higher quartile, left column) and negative (lower quartile, right column) phases of $\mathrm{MO}_{\mathrm{PC}}$ index.

the potential to generate major changes in the strength of the air-sea coupling, while this is not the case in summer [10]. Winter heat loss events have been linked to the Eastern Mediterranean Transient [31], deep water formation processes [11, 12], and the recent deep water production in the western Mediterranean from 2004 to 2006 [32, 33]. For this reason, most studies focus on this season and the same analysis has been performed for all MO indices in wintertime, when pressure patterns over the Mediterranean are better established and the station-based indices are likely to improve their ability to represent the atmospheric forcing. The first issue to be noticed is that the correlation among all MO indices is much higher now (above 0.7 in most cases, Table 5) and similarity in their effect on climatic variables is then expected.

Table 1 (lower panel) displays the correlation results (absolute value) between the winter variables and the different MO indices analysed (results are fairly similar if the period is extended to the entire cold season from November to March). On an annual basis, $\mathrm{MO}_{\mathrm{AC}}$ shows the highest correlation for $P, E$, and $Q$, whereas $E-P$ is better correlated with
TABLE 5: Correlation (95\% significance level) among all the selected $\mathrm{MO}$ indices (winter-averaged time series): $\mathrm{MO}_{\mathrm{PC}}$ based on principal component analysis and the other station-based $\mathrm{MO}$ indices $\left(\mathrm{MO}_{\mathrm{AC}}\right.$ for Algiers-Cairo; $\mathrm{MO}_{\mathrm{GI}}$ for Gibraltar-Israel; $\mathrm{MO}_{\mathrm{FL}}$ for FranceLevantine; and $\mathrm{MO}_{\mathrm{MJ}}$ for Marseille-Jerusalem; see text for details).

\begin{tabular}{lcccc}
\hline & $\mathrm{MO}_{\mathrm{PC}}$ & $\mathrm{MO}_{\mathrm{AC}}$ & $\mathrm{MO}_{\mathrm{GI}}$ & $\mathrm{MO}_{\mathrm{FL}}$ \\
\hline $\mathrm{MO}_{\mathrm{AC}}$ & 0.74 & & & \\
$\mathrm{MO}_{\mathrm{GI}}$ & 0.73 & 0.62 & & \\
$\mathrm{MO}_{\mathrm{FL}}$ & 0.74 & 0.65 & 0.76 & \\
$\mathrm{MO}_{\mathrm{MI}}$ & 0.87 & 0.80 & 0.81 & 0.93 \\
\hline
\end{tabular}

$\mathrm{MO}_{\mathrm{PC}}$. Figure 4 shows the correlation spatial patterns for $\mathrm{MO}_{\mathrm{PC}}$ and $\mathrm{MO}_{\mathrm{AC}}$ (representative of all station-based indices) and similarity is rather evident. Winter precipitation is highly correlated with both indices ( $r \geq 0.5$ on average, Table 1) with higher (negative) values in the western basin (Figures 4(a)4(b)), whereas positive correlation is restricted to the southeasternmost areas. Winter precipitation is generally linked to storm-track activity related to pressure distribution and 


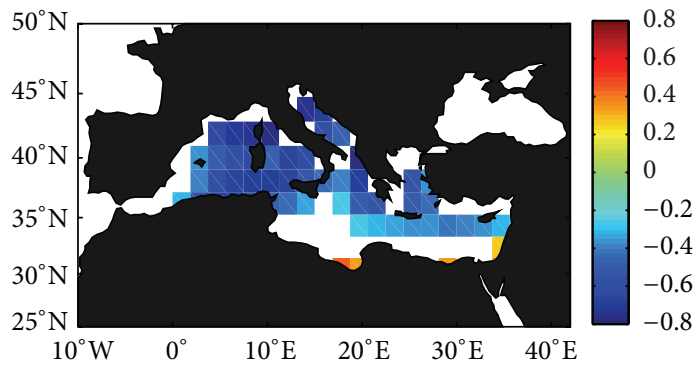

(a)

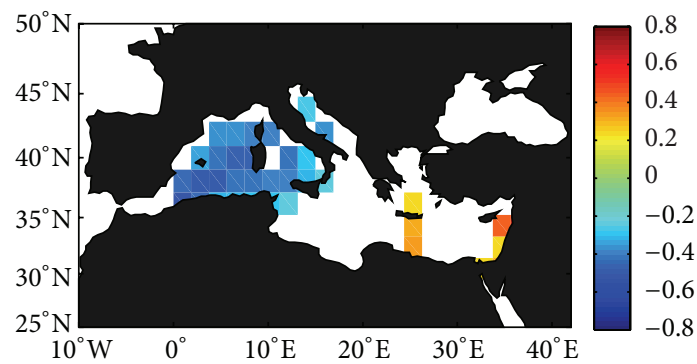

(c)

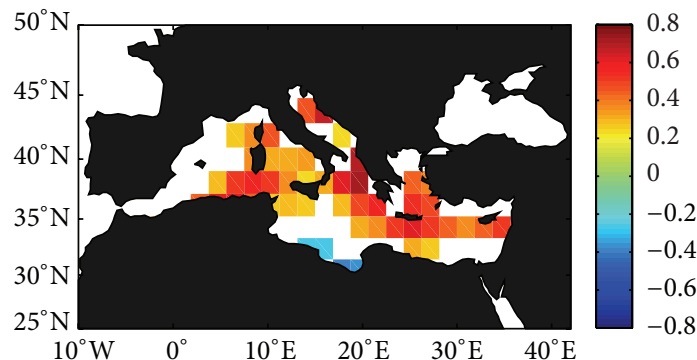

(e)

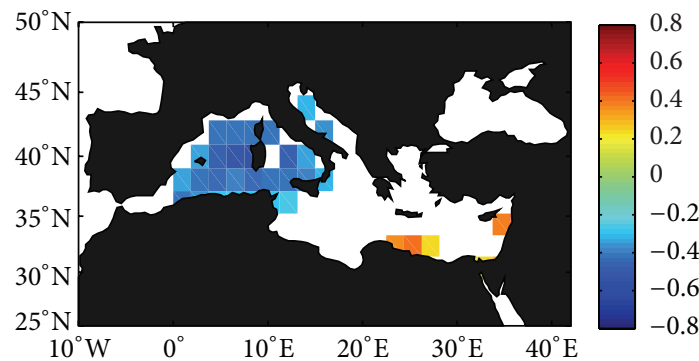

(g)

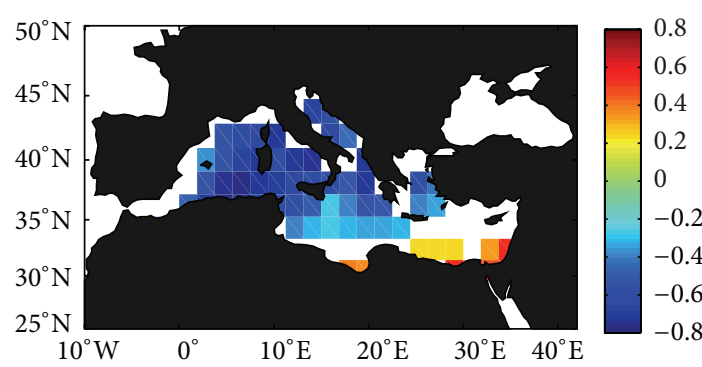

(b)

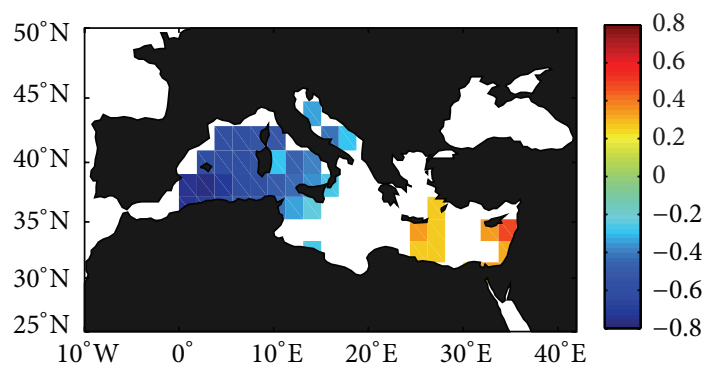

(d)

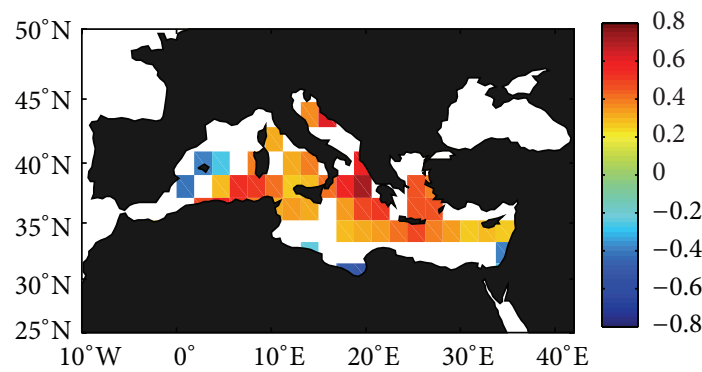

(f)

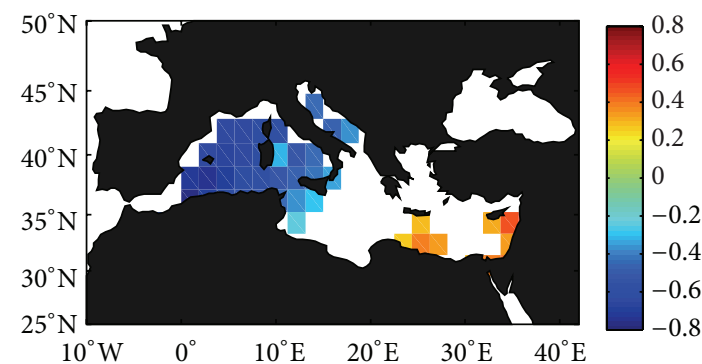

(h)

FIGURE 4: Correlation spatial pattern (95\% significance) between winter-averaged $\mathrm{MO}_{\mathrm{PC}}$ (left column) and $\mathrm{MO}_{\mathrm{AC}}$ (right column) indices and the selected climatic variables: precipitation ((a)-(b)), evaporation ((c)-(d)), freshwater budget $E-P((\mathrm{e})-(\mathrm{f}))$, and net heat flux $((\mathrm{g})-(\mathrm{h}))$ for the period 1958-2008.

hence captured by atmospheric indices, whereas in summer most of precipitation across the Mediterranean region is of convective origin and is poorly correlated with the large-scale atmospheric forcing.

Winter evaporation is not so well correlated with the atmospheric indices $\left(\sim 0.5\right.$ on average for $\mathrm{MO}_{\mathrm{AC}}$ and about 0.4 for the other MO indices, Table 1). All MO indices (with the only exception of $\mathrm{MO}_{\mathrm{GI}}$, which only affects $E$ in a much reduced fraction of the basin) produce a dipole response with negative correlation in the western basin and positive in the eastern (Figures 4(c)-4(d)). This dipole is more evident for $\mathrm{MO}_{\mathrm{AC}}$ (Figure $4(\mathrm{~d})$ ), for which more points are significantly correlated at $95 \%$. However, it is important to mention that the dipole behaviour is clearly revealed if the significance is set to $90 \%$. The winter freshwater budget $E-P$ is well correlated with the $\mathrm{MO}$ indices $\left(\sim 0.45\right.$ on average for $\mathrm{MO}_{\mathrm{PC}}$ and $\mathrm{MO}_{\mathrm{AC}}$ over almost $60 \%$ of the basin and similar results for the other MO indices; see Table 1). Correlation is positive almost everywhere (Figures 4(e)-4(f)) due to the dominant effect of precipitation in winter and the positive correlation 


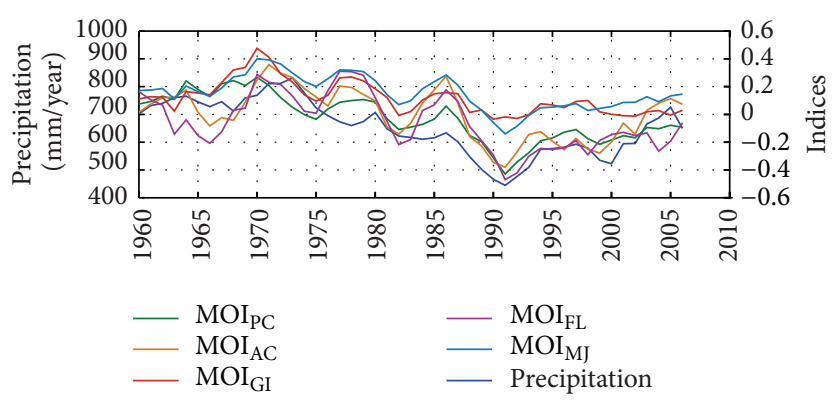

FIgURE 5: Time series of decadal (5-winter running means) Mediterranean-averaged winter precipitation ( $\mathrm{mm} /$ year, left axis) and the selected $\mathrm{MO}$ climatic indices (right axis, $\mathrm{MO}_{\mathrm{AC}}$ for AlgiersCairo; $\mathrm{MO}_{\mathrm{GI}}$ for Gibraltar-Israel; $\mathrm{MO}_{\mathrm{FL}}$ for France-Levantine; $\mathrm{MO}_{\mathrm{MJ}}$ for Marseille-Jerusalem; and $\mathrm{MO}_{\mathrm{PC}}$ based on principal components analysis). Notice that the interannual variability is of interest more than the value of the indices itself.

with $E$ in the western basin (remember that, on annual basis, the evaporation contribution was dominant in extensive areas of the Levantine basin, Figure 2(c)). As previously mentioned, the net heat flux spatial pattern (Figures 4(g)4(h)) and correlation results (Table 1) are very similar to those of evaporation because latent heat is the main source of interannual net heat variability [30].

At decadal timescales (5-winter running means), all MO indices tend to improve the correlation with the climatic variables (and also the fraction of points significantly correlated) and similarity among them is even more evident, $\mathrm{MO}_{\mathrm{PC}}$ providing slightly the highest correlation in general (see values in Table 1). It is important to mention that the dipole response revealed at winter-averaged annual basis (especially for $E$ and Q) tends to reduce at decadal timescale, probably due to a masking of the results in the long-time period. Basin-wide, high (negative) correlation is observed for winter precipitation with all $\mathrm{MO}$ indices, especially $\mathrm{MO}_{\mathrm{PC}}$, with $r=$ -0.87 (Table 2; see Figure 5 for time series). Winter $E-P$ is also very well correlated with the indices, $\mathrm{MO}_{\mathrm{MJ}}$ reaching the highest value $(r=0.80)$. Notice that evaporation and net heat flux are poorly (or not significantly) correlated with the MO indices due to its dipole influence that promotes correlation of opposite sign in the eastern and western basins.

To summarise, during wintertime the station-based indices highly improve their ability to represent the well-established atmospheric pressure pattern over the Mediterranean and all of them tend to converge to similar results. $\mathrm{MO}_{\mathrm{AC}}$ gives the highest correlation for most winter-averaged variables and reveals more clearly the well-known dipole response of the eastern and western basins. At decadal timescales, all MO indices show fairly similar results (slightly higher for $\mathrm{MO}_{\mathrm{PC}}$, Table 1 in bold).

\section{Summary and Concluding Remarks}

Two different paradigms of the Mediterranean Oscillation teleconnection index have been analysed in this work: station-based definitions obtained by the difference of some climate variable between two selected points in the eastern and western basins (Algiers-Cairo for $\mathrm{MO}_{\mathrm{AC}}$, Gibraltar-Israel for $\mathrm{MO}_{\mathrm{GI}}$, Marseille and Jerusalem for $\mathrm{MO}_{\mathrm{MJ}}$, or FranceLevantine for $\mathrm{MO}_{\mathrm{FL}}$ ) and the principal component (PC) approach in which the $\mathrm{MO}_{\mathrm{PC}}$ index is obtained as the time series of the first mode of normalised sea level pressure anomalies across the extended Mediterranean region $\left(30^{\circ} \mathrm{W}-\right.$ $40^{\circ} \mathrm{E}$ in longitude, $30^{\circ} \mathrm{N}-60^{\circ} \mathrm{N}$ in latitude). We have correlated interannual to interdecadal precipitation $(P)$, evaporation $(E), E-P$, and net heat flux with the different $\mathrm{MO}$ indices to compare their relative importance in the long-term variability of heat and freshwater budgets over the Mediterranean Sea.

On an annual basis, the PC paradigm is the most effective tool to assess the effect of the large-scale atmospheric forcing in the Mediterranean Sea because the station-based indices exhibit a very poor correlation with all climatic variables and only influence a reduced fraction of the basin. A disadvantage of the station-based indices is that they are fixed in space and are significantly affected by small-scale and transient meteorological events that introduce noise $[34,35]$. In contrast, we have shown that the principal component approach provides a more optimal representation of the full spatial pattern and constitutes a better paradigm for the large-scale atmospheric forcing.

In winter, the atmosphere is dynamically more active and large-scale patterns of atmospheric variability have the potential to generate major changes in the strength of the airsea coupling than in other seasons. Pressure patterns over the Mediterranean are better established and the stationbased indices highly improve their ability to represent the atmospheric forcing. $\mathrm{MO}_{\mathrm{AC}}$ gives the highest correlation for most winter-averaged variables and reveals more clearly the well-known dipole response of the eastern and western basins. However, all MO indices show fairly similar results, especially at decadal timescales.

\section{Acknowledgments}

This work has been carried out in the frame of the P07RNM-02938 Junta de Andalucia Spanish-funded project. Javier Soto-Navarro acknowledges a postgraduate fellowship from Conserjería de Innovación Ciencia y Empresa, Junta de Andalucía, Spain. NCEP data have been provided by the NOAA/OAR/ESRL PSD, Boulder, Colorado, USA, from their website at http://www.esrl.noaa.gov/psd/. $\mathrm{MO}_{\mathrm{GI}}$ index has been obtained from the Climate Research Unit (CRU), University of East Anglia at their website http://www.cru.uea.ac.uk/cru/data/moi/. $\mathrm{MO}_{\mathrm{AC}}$ has been computed for the authors by Ian Harris from CRU routines for which the authors are indebted to him. The authors are also very grateful to Dr. V. Papadopoulos for sharing his $\mathrm{MO}_{\mathrm{FL}}$ data and to Dr. Jacobeit for his assistance.

\section{References}

[1] M. Tsimplis, V. Zervakis, S. A. Josey et al., "Changes in the oceanography of the Mediterranean Sea and their link to climate variability," in Mediterranean Climate Variability Amsterdam, the Netherlands, P. Lionello, P. Malanotte-Rizzoli, and 
R. Boscolo, Eds., vol. 4 of Developments in Earth and Environmental Sciences, pp. 227-282, Elsevier, 2006.

[2] J.-P. Béthoux, B. Gentili, and D. Tailliez, "Warming and freshwater budget change in the Mediterranean since the 1940s, their possible relation to the greenhouse effect," Geophysical Research Letters, vol. 25, no. 7, pp. 1023-1026, 1998.

[3] R. A. Potter and M. S. Lozier, "On the warming and salinification of the Mediterranean outflow waters in the North Atlantic," Geophysical Research Letters, vol. 31, no. 1, Article ID L01202, 2004.

[4] V. Artale, S. Calmanti, P. Malanotte-Rizzoli, G. Pisacane, V. Rupolo, and M. Tsimplis, "The Atlantic and the Mediterranean Sea as connected systems," in Mediterranean Climate VariabilityAmsterdam, the Netherlands, P. Lionello, P. MalanotteRizzoli, and R. Boscolo, Eds., vol. 4 of Developments in Earth and Environmental Sciences, pp. 283-323, Elsevier, 2006.

[5] C. Millot, J. Candela, J.-L. Fuda, and Y. Tber, "Large warming and salinification of the Mediterranean outflow due to changes in its composition," Deep-Sea Research, vol. 53, no. 4, pp. 656666, 2006.

[6] G. T. Walker and W. E. Bliss, "World weather V. Memories of the royal meteorological," Society, vol. 44, pp. 53-84, 1932.

[7] H. van Loon and J. C. Rogers, "The see-saw of winter temperatures between Greenland and northern Europe. Part I: general descriptions," Monthly Weather Review, vol. 106, pp. 296-310, 1978.

[8] A. G. Barnston and R. E. Livezey, "Classification, seasonality and persistence of low-frequency atmospheric circulation patterns," Monthly Weather Review, vol. 115, no. 6, pp. 1083-1126, 1987.

[9] J. W. Hurrell, Y. Kushnir, G. Ottersen, and M. Visbeck, The North Atlantic Oscillation: Climate Significance and Environmental Impact, vol. 134 of Geophysical Monograph Series, 2003.

[10] S. A. Josey, S. Somot, and M. Tsimplis, "Impacts of atmospheric modes of variability on Mediterranean Sea surface heat exchange," Journal of Geophysical Research C, vol. 116, no. 2, Article ID C02032, 2011.

[11] V. P. Papadopoulos, H. Kontoyiannis, S. Ruiz, and N. Zarokanellos, "Influence of atmospheric circulation on turbulent air-sea heat fluxes over the Mediterranean Sea during winter," Journal of Geophysical Research C, vol. 117, no. 3, Article ID C03044, 2012.

[12] V. Papadopoulos, S. Josey, A. Bartzokas, S. Somot, S. Ruiz, and P. Drakopoulou, "Large-scale atmospheric circulation favoring deep -and intermediate- water formation in the Mediterranean Sea," Journal of Climate, vol. 25, pp. 6079-6091, 2012.

[13] H. Kutiel and Y. Benaroch, "North Sea-Caspian pattern (NCP) - an upper level atmospheric teleconnection affecting the Eastern Mediterranean: identification and definition," Theoretical and Applied Climatology, vol. 71, no. 1-2, pp. 17-28, 2002.

[14] H. Kutiel, P. Maheras, M. Türkeş, and S. Paz, "North Sea Caspian Pattern (NCP) - an upper level atmospheric teleconnection affecting the eastern Mediterranean-implications on the regional climate," Theoretical and Applied Climatology, vol. 72, no. 3-4, pp. 173-192, 2002.

[15] M. Gündüz and E. Özsoy, "Effects of the North Sea Caspian pattern on surface fluxes of Euro-Asian-Mediterranean seas," Geophysical Research Letters, vol. 32, Article ID L21701, 2005.

[16] M. Brunetti and H. Kutiel, "The relevance of the North-Sea Caspian Pattern (NCP) in explaining temperature variability in Europe and the Mediterranean," Natural Hazards and Earth System Science, vol. 11, no. 10, pp. 2881-2888, 2011.
[17] M. Conte, A. Giuffrida, and S. Tedesco, "The Mediterranean Oscillation, impact on precipitation and hydrology in Italy," in Conference on Climate Water, pp. 121-137, Publications of the Academy of Finland, Helsinki, 1989.

[18] H. Kutiel, P. Maheras, and S. Guika, "Circulation indices over the Mediterranean and Europe and their relationship with rainfall conditions across the Mediterranean," Theoretical and Applied Climatology, vol. 54, no. 3-4, pp. 125-138, 1996.

[19] P. Maheras, E. Xoplaki, and H. Kutiel, "Wet and dry monthly anomalies across the Mediterranean basin and their relationship with circulation, 1860-1990," Theoretical and Applied Climatology, vol. 64, no. 3-4, pp. 189-199, 1999.

[20] N. Supić, B. Grbec, I. Vilibić, and I. Ivančić, "Long-term changes in hydrographic conditions in northern Adriatic and its relationship to hydrological and atmospheric processes," Annales Geophysicae, vol. 22, no. 3, pp. 733-745, 2004.

[21] J. Jacobeit, S. Seubert, and A. Dünkeloh, "Links of the Mediterranean Oscillation to mid-latitude and tropical climate dynamics," Proceedings of the 2nd ESF MedCLIVAR Workshop: Connection between Mediterranean and Global Climate Variability, Toulon, France, 2007, http://www.medclivar.eu/workshop_2 .html.

[22] T. Törnros, "On the relationship between the Mediterranean Oscillation and winter precipitation in the Southern Levant," Atmospheric Science Letters, vol. 14, no. 4, pp. 287-293, 2013.

[23] J. P. Palutikof, "Analysis of Mediterranean climate data: measured and modelled," in Mediterranean Climate: Variability and Trends, H. J. Bolle, Ed., Springer, Berlin, Germany, 2003.

[24] M. Brunetti, M. Maugeri, and T. Nanni, "Atmospheric circulation and precipitation in Italy for the last 50 years," International Journal of Climatology, vol. 22, no. 12, pp. 1455-1471, 2002.

[25] K. Suselj and K. Bergant, Mediterranean Oscillation Index, Geophysical Research Abstracts 8, 02145 European Geosciences Union, 2006.

[26] D. Gomis, M. N. Tsimplis, B. Martín-Míguez, A. W. Ratsimandresy, J. García-Lafuente, and S. A. Josey, "Mediterranean Sea level and barotropic flow through the Strait of Gibraltar for the period 1958-2001 and reconstructed since 1659," Journal of Geophysical Research C, vol. 111, no. 11, Article ID C11005, 2006.

[27] E. Kalnay, M. Kanamitsu, R. Kistler et al., "The NCEP/NCAR 40-year reanalysis project," Bulletin of the American Meteorological Society, vol. 77, no. 3, pp. 437-471, 1996.

[28] D. Pettenuzzo, W. G. Large, and N. Pinardi, "On the corrections of ERA-40 surface flux products consistent with the Mediterranean heat and water budgets and the connection between basin surface total heat flux and NAO," Journal of Geophysical Research C, vol. 115, no. 6, Article ID C06022, 2010.

[29] J. W. Hurrell, "Decadal trends in the North Atlantic Oscillation: regional temperatures and precipitation," Science, vol. 269, no. 5224, pp. 676-679, 1995.

[30] F. Criado-Aldeanueva, F. J. Soto-Navarro, and J. GarcíaLafuente, "Seasonal and interannual variability of surface heat and freshwater fluxes in the Mediterranean Sea: budgets and exchange through the Strait of Gibraltar," International Journal of Climatology, vol. 32, no. 2, pp. 286-302, 2012.

[31] S. A. Josey, "Changes in the heat and freshwater forcing of the eastern Mediterranean and their influence on deep water formation," Journal of Geophysical Research C, vol. 108, no. 7, 2003.

[32] K. Schroeder, S. A. Josey, M. Herrmann, L. Grignon, G. P. Gasparini, and H. L. Bryden, "Abrupt warming and salting of 
the Western Mediterranean Deep Water after 2005: atmospheric forcings and lateral advection," Journal of Geophysical Research C, vol. 115, no. 8, Article ID C08029, 2010.

[33] M. Herrmann, F. Sevault, J. Beuvier, and S. Somot, "What induced the exceptional 2005 convection event in the northwestern Mediterranean basin? Answers from a modeling study," Journal of Geophysical Research C, vol. 115, no. 12, Article ID C12051, 2010.

[34] K. E. Trenberth, "Signal versus noise in the Southern Oscillation," Monthly Weather Review, vol. 112, no. 2, pp. 326-332, 1984.

[35] J. W. Hurrell and H. Van Loon, "Decadal variations in climate associated with the North Atlantic oscillation," Climatic Change, vol. 36, no. 3-4, pp. 301-326, 1997. 

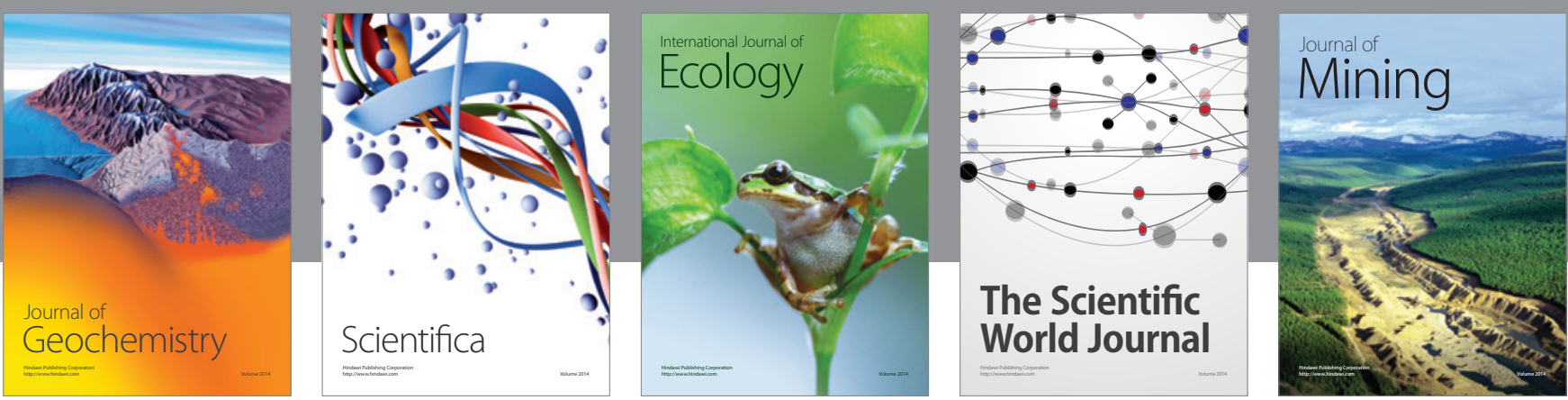

The Scientific World Journal
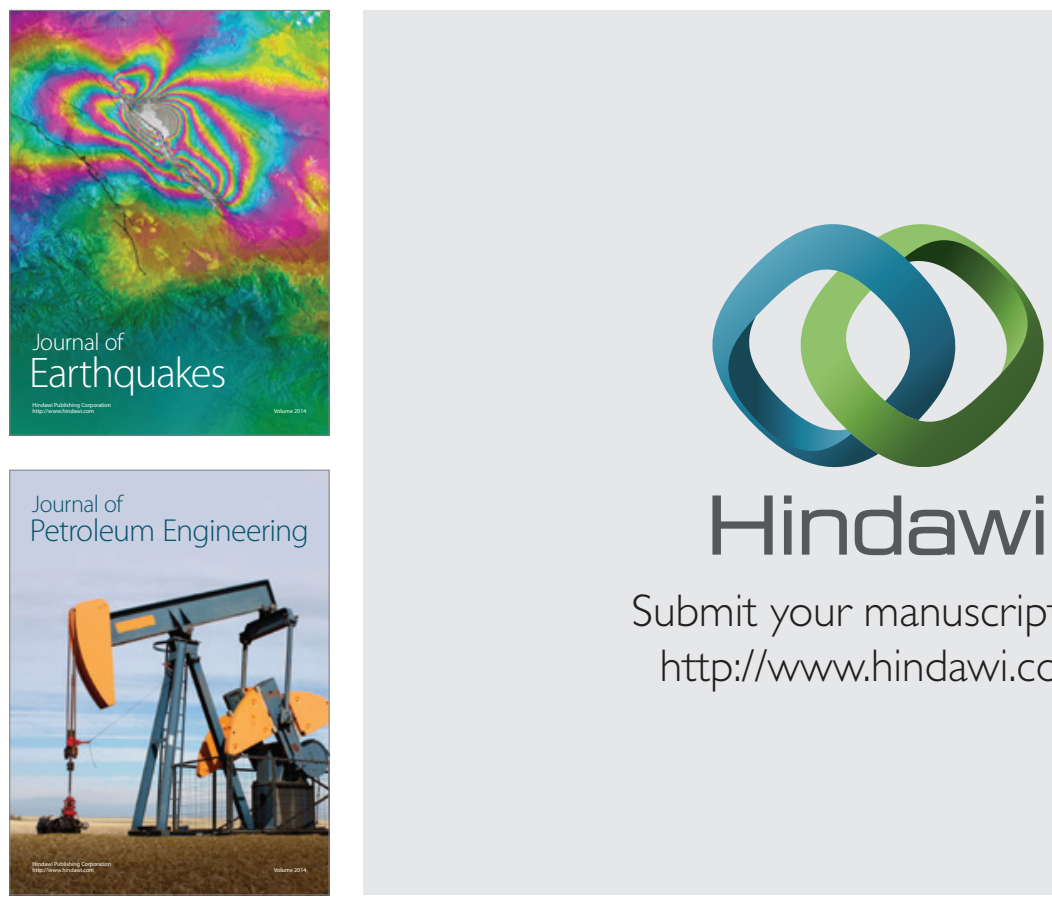

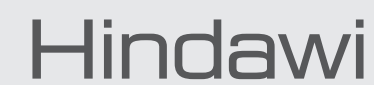

Submit your manuscripts at

http://www.hindawi.com
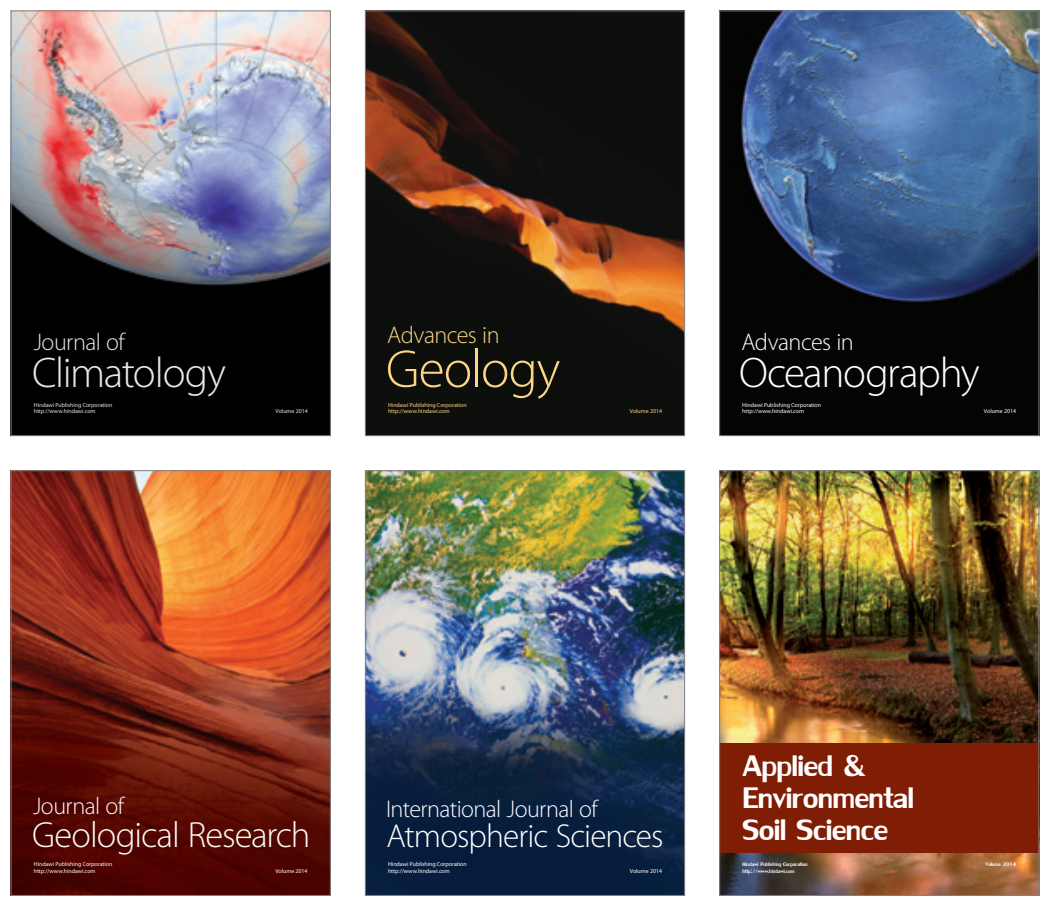
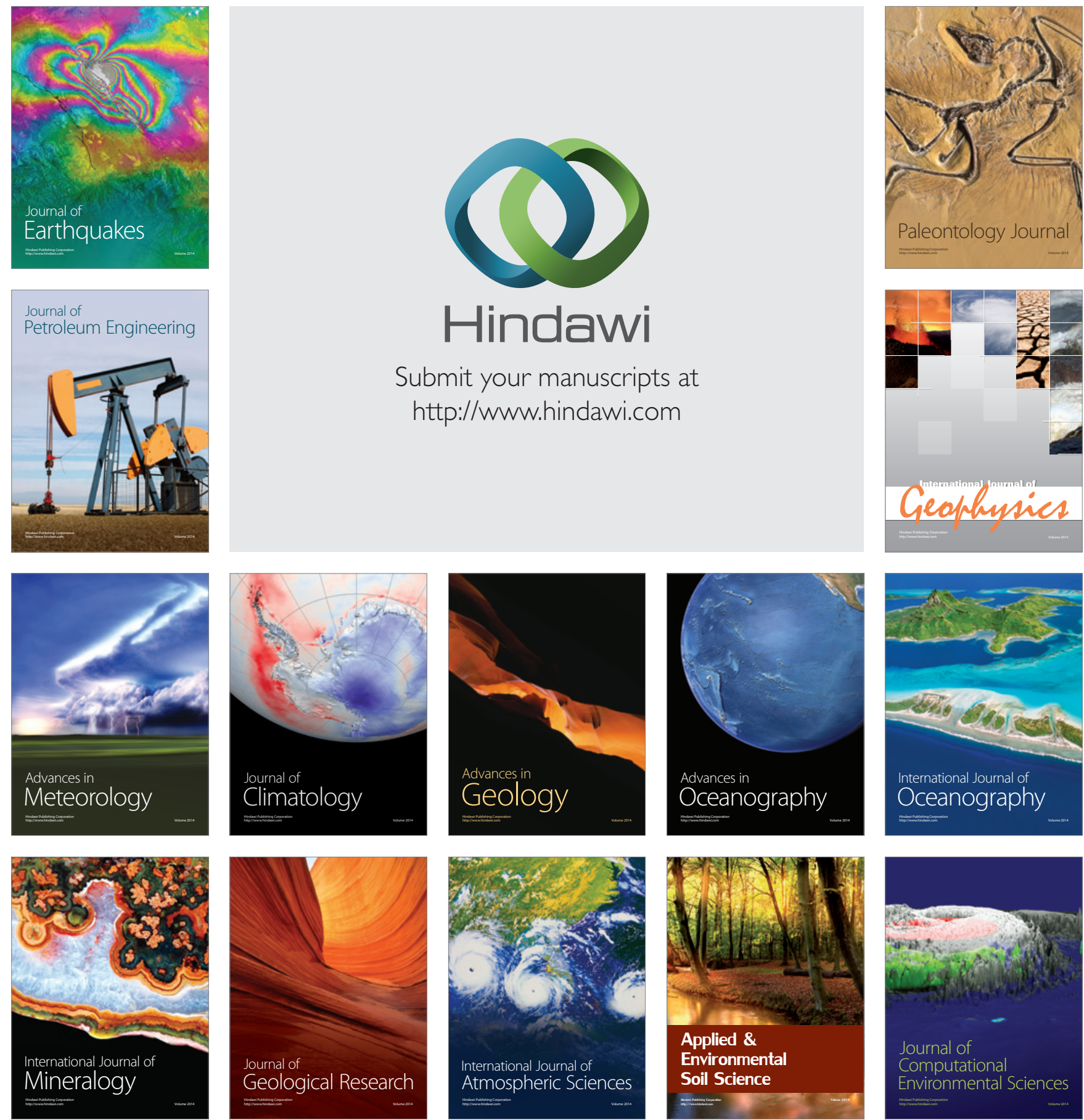